Abstracta Iranica Iranica

Revue bibliographique pour le domaine irano-aryen

Volume 34-35-36 | 2017

Comptes rendus des publications de 2011-2013

\title{
Emanuel Petac, Aurelian Ionescu. Some Sasanian \\ Silver Coins Discovered at Axiopolis, Cernavodă, Constanţa County, Romania
}

\section{Rika Gyselen}

\section{OpenEdition}

1 Journals

\section{Édition électronique}

URL : http://journals.openedition.org/abstractairanica/42332

DOI : 10.4000/abstractairanica.42332

ISSN : 1961-960X

Éditeur :

CNRS (UMR 7528 Mondes iraniens et indiens), Éditions de l'IFRI

Référence électronique

Rika Gyselen, «Emanuel Petac, Aurelian Ionescu. Some Sasanian Silver Coins Discovered at Axiopolis, Cernavodă, Constanta County, Romania », Abstracta Iranica [En ligne], Volume 34-35-36 | 2017, document 49, mis en ligne le 30 juillet 2017, consulté le 02 octobre 2020. URL : http://journals.openedition.org/ abstractairanica/42332 ; DOI : https://doi.org/10.4000/abstractairanica.42332

Ce document a été généré automatiquement le 2 octobre 2020.

Tous droits réservés 


\title{
Emanuel Petac, Aurelian Ionescu. Some Sasanian Silver Coins Discovered at Axiopolis, Cernavodă, Constanţa County, Romania
}

\author{
Rika Gyselen
}

\section{RÉFÉRENCE}

Emanuel Petac, Aurelian Ionescu. « Some Sasanian Silver Coins Discovered at Axiopolis, Cernavodă, Constanţa County, Romania ». IA, 48, 2013, p. 355- 361.

Parmi les centaines de monnaies découvertes sur les pentes de la forteresse d'Axiopolis en Roumanie figurent cinq drahms sassanides. Les AA. passent en revue l'histoire de cette citadelle d'abord romaine, puis byzantine, pour trouver une explication à la présence de ces quelques monnaies dont la plus ancienne date du règne de Šābuhr I ${ }^{\text {er }}$ (242-271) et la plus récente de Husraw II (590-626).

\section{AUTEURS}

RIKA GYSELEN

CNRS, Mondes iranien et indien 